\title{
Strategy to build brand image in increasing public interest in Islamic educational institutions (Multisite study at MA Ma'arif NU Blitar and MA Ma'arif Udanawu Blitar)
}

\author{
Erwin Indrioko ${ }^{\mathrm{a}}$, Mujamil $^{\mathrm{b}}$, Prim Masrokan Mutohar ${ }^{\mathrm{c}}$, Maftukhin $^{\mathrm{d}}$, Akhyak $^{\mathrm{e}}$ \\ aindriokoerwin@gmail.com \\ ${ }^{a}$ IAIN Kediri, East Java, Indonesia \\ ${ }^{b, c, d, e}$ UIN Satu Tulungagung, East Java, Indonesia
}

\begin{abstract}
A good brand image in an Islamic educational institution has an attraction for public interest in using the educational services provided. Brand image does not come by itself but is built by all existing human resources. Brand image is an important factor for an educational institution because it serves as a differentiating identity from other institutions and as a natural promotional asset in society. This study aims to analyze and find strategy in building brand image of Islamic educational institutions to increase public interest carried out by MA Ma'arif NU Blitar City and MA Ma'arif Udanawu Blitar Regency. This research uses a qualitative approach and is a case study research type with a multi-site research design. Data collection techniques were carried out by (1) in-depth interviews, (2) participatory observation, (3) documentation. Data analysis was carried out with steps of data collection, data reduction, data condensation, data display, and drawing conclusion. The results of this study found that the strategy in building a brand image in Islamic educational institutions is carried out by holding direct or face-to-face meetings with the community and utilizing mass media or social media to build positive impression in the minds of the public.
\end{abstract}

Keywords: Brand Image, public interest, Islamic Educational Institutions

\section{Introduction}


In the history of human civilization, there is almost no group of people who do not use education as a means of civilizing and improving the quality of individual human resources. A society that has an advanced civilization must be supported by a strong education system. Many developed countries have poured huge funds to pursue the quality of education implementation because education is the most effective and efficient means to transform science, technology, culture in preparing the next generation. In this case, education plays an important role to form reliable human resources in filling progress in all fields. Like what Nelson Mandela said that "Education is the most powerful weapon, we can use to change the world" 1 .

The dynamics of education in Indonesia is undergoing an interesting transformation process, from a traditional education system where the implementation is at home or at a mosque to the emergence of modern formal education today, education continues to move to accompany the life of a pluralistic Indonesian society. ${ }^{2}$ Islamic education is one of the components that color the journey of education in Indonesia. Even Islamic education has a unique educational model as a characteristic of education in Indonesia, for example, the Islamic boarding school model education. Along with the journey to fulfill Indonesia's basic human need for education, various forms and models of education have been offered. Starting from education in the form of Al-Qur'an Educational Parks, Salafi boarding schools, Modern Islamic Boarding Schools, Madrasas, and even Boarding School education models also color Islamic education models. This encouraging development had two significant impacts; First, Islamic educational institutions provide a variety of educational options for the community, especially Muslims, for adequate education. The various forms of educational models actually give birth to positive competition between Islamic educational institutions to provide the best

\footnotetext{
1 A. Gebremedhin and Joshi, Social Justice And Human Rights In Education Policy Discourse: Assessing Nelson Mandela's Legacy, UNISA Journal. Vol 20 No 1. 2016. Page 174.

${ }^{2}$ Charlene Tan, Educative Tradition and Islamic Schools in Indonesia, Journal of Arabic and Islamic Studies. Vol 14 (2014): Page 47.
} 
service for the community. Second, Islamic educational institutions are required to provide characteristics that are more different from other general education. The ability to win public interest by providing adequate services in every field contributes greatly to the existence of Islamic educational institutions.

Constitution no. 20 of 2003 concerning the national education system provides a great opportunity as well as a challenge for Islamic educational institutions to immediately provide and prioritize the ideal model of education services. This can be seen in the introduction to the Republic of Indonesia Law No. 20 of 2003 which reads, that the national education system must be able to ensure equal distribution of educational opportunities, improve quality as well as the relevance and efficiency of education management to face challenges in accordance with the demands of changes in local, national and global life so that education reforms are needed in a planned, directed and sustainable.

With the continued increase in the number of madrasas and the increasing number of students, the hope of Islamic education to grow and develop from year to year is always there. This must be accompanied by continuous improvement in terms of the quality of its management, curriculum, learning process, teaching staff, infrastructure, financing, graduates and so on. The main thing that must receive serious attention is the human resource management, as stated by Yakov Kedem et al, "Higher education institutions face technological, economic, social and Political changes that force them to make drastic adjustments in order to survive. This adjustments require professioanalism not only in the higher levels of management but also in the meadle and lower levels". ${ }^{3}$ The country of Indonesia with the largest quantity of Muslim population in the world must be accompanied by a qualified quality of Islamic education, so that Islamic educational institutions in Indonesia in

\footnotetext{
${ }^{3}$ Yakov Kedem \& Mueen Fakhereldeen, A Frame Work For The Training And Development Of Academic Managers In Higher Educations. Journal Of Internasional Scientific Publications: Educational Alternatives, Vol 10 Part 1, 2012. Page 116.
} 
the future produce quality human resources graduates and become mouthpieces of Islamic education in the world community.

Brand image in Islamic educational institutions is an interesting theme to study because the research output will be the theoretical and practical basis that helps educational institutions to be recognized by the wider community, as a differentiating identity from other educational institutions, and as a promotional asset that flows naturally in the middle of education. the middle of society. Islamic educational institutions will be able to compete with other educational institutions if they make brand image an important factor for marketing the educational services they provide.

A strong brand image affects people's interest in using the educational services offered. The better the brand image that is built, the more people will look at the educational services offered. This proves that the brand image of an educational institution is important to build, so that Islamic educational institutions are able to compete positively based on achievement and good academic services. For this reason, research on the brand image of Islamic educational institutions needs to be explored in detail and in depth. In this study, researchers will explore strategies to build brand image carried out in two institutions, namely MA Ma'arif NU Blitar City and MA Ma'arif Udanawu Blitar Regency with the hope that this research will become a mirror and material for introspection for Islamic educational institutions to improve quality. and services, as well as how Islamic educational institutions are able to survive and exist in the midst of the competitive map between educational institutions at the local, national and even international levels.

\section{Research Method}

This research is expected to find and describe comprehensively the strategy of building a brand image of Islamic educational institutions in increasing public interest in MA Ma'arif NU Blitar City and MA Ma'arif Udanawu Blitar. Thus, this study uses a qualitative approach because it seeks to explore and describe the strategy of Islamic 
educational institutions in building a brand image as an effort to remain known to the wider community. This study uses a multi-site study research design, where this study explores in depth in 2 locations of Islamic education which are considered to have the same characteristics and similarity of the object under study. In this study, the researcher collected data by conducting: participant observation, in-depth interviews, and documentation. In this study, two data analyzes were used, namely; in-site data analysis and cross-site data analysis.

\section{Discussion}

Strategy in building a brand image to increase public interest in MA Ma'arif NU Blitar City and MA Ma'arif Udanawu Blitar Regency use direct and indirect strategies.

\section{a. Direct Strategy}

The direct strategy is by dealing directly with the community as the target of building branding. Implementation of the direct strategy is to invite the community and come to the community. The activity of visiting the community directly at the MA Ma'arif NU in Blitar City is carried out by means that some students on every Sunday morning are directed to attend recitations at the Great Mosque of Alun-Alun Blitar. The presence of the MA Ma'arif NU students was indeed invited by the ta'mir of the mosque, but this could be used as a means of showing their existence to the community. As for some of the lecturers at the Great Mosque of Alun-Alun Blitar, there were clerics from the Nurul Ulum Islamic Boarding School. The next program is PKL (field work practice), where grade 12 students who will graduate are required to take part in the PKL program. The students who take part in the PKL program are distributed to the southern and northern Blitar areas. Each village has 7-8 students to serve about religious 
knowledge in that place. The next activity was that the teachers who were also preachers during lectures in various regions were also ordered to introduce the institutions and communities that attended to see the large number of recitations being the target of publication. Efforts to visit the community are a proactive way for madrasas as a method to publish madrasas directly to the wider community or called external publications whose targets are outside public audiences. ${ }^{4}$ According to Nisberg's opinion that publication is information to show, introduce, defend the name and honor of a person, group, or organization to the audience in a certain context with the aim of creating audience attraction. ${ }^{5}$ The purpose of Islamic educational institutions by visiting the community is to show the existence of the existence of the institution, this is also one way to show programs, activities, achievements, student services that should be known by the public. Through these methods, a brand image will be formed in the community.

The method of inviting the public at the MA Ma'arif Udanawu, Blitar district, is by carrying out graduation activities, istighosah, student guardian meetings for new teachings, taking report cards, holding general recitations, collaborating with various parties, implementing MTs/SMP level try out exams. One of the effective ways of promotion to the community at MA Ma'arif Udanawu Blitar Regency is to invite junior high school/MTs level students in the Blitar, Tulungagung, and Kediri areas to take part in the National Examination Try Out activity, in the Try Out activity all facilities and services are shown education held by MA Ma'arif Udanawu. So that the try out participants are interested and interested in continuing their education at MA Ma'arif Udanawu. The implementation of the try out at MA Ma'arif Udanawu reinforces what Alma said that marketing ethics in the world of education should offer quality intellectual

\footnotetext{
${ }^{4}$ Fariani dan Ariyanto, Public Relations Profesi dan Praktik. Jakarta: Salemba Humanika, 2009. Page 69.

${ }^{5}$ Teguh Tri Susanto, Penggunaan Spanduk Dan Brosur Sebagai Bahan Penunjang Media Publikasi Kegiatan, Jurnal ABDIMAS BSI, Vol 1 no 3 2018. Page 577.
} 
services and shape character as a whole. ${ }^{6}$ In addition to this, MA Ma'arif Udanawu is very concerned with excellent service for educational services offered to the community. The excellent service provided by MA Ma'arif Udanawu is related to 3 things. One, for educational services to students, especially those related to religious knowledge, general knowledge, and skills; two, for the excellent service provided when inviting parents and guardians to the madrasa; three, service the rights and obligations of neighbors to the community around the madrasa. Meanwhile, the activity of inviting the public at the MA Ma'arif NU in Blitar City was to carry out graduation activities which were attended by walisantri, memorized Akhirusannah, and istighosah kubro activities. As one way to promote their services, all leaders of Ma'arif NU in Blitar City market madrasas directly through the NU organization management forum, from the branch level to the NU management branch, this is considered to have a significant impact because information quickly spreads to all city nahdliyin residents / Blitar Regency. The activities carried out in the two locations above are in order to promote the institution directly, M. Mursid stated that promotion is a form of marketing communication, namely marketing activities that seek to disseminate information, influence or persuade, or remind the target market of the institution and its products to be willing to accept, buy and loyal to the products offered by the institution. ${ }^{7}$ Implementation of promotions in both research locations by showing the existence of madrasas and also determining promotion targets directly is a way for people to believe and be interested in becoming consumers of education, in the sense that they are willing to take advantage of educational services held in both locations.

The direct strategy by visiting and inviting the community and providing the best service for the community is aimed at building a positive perception

${ }^{6}$ Buchari Alma, Manajemen Pemasaran Manajemen Pemasaran dan Pemasaran Jasa. Bandung: Alfabeta, 2019. Page 49.

${ }^{7}$ M.Mursid, Manajemen Pemasaran .Jakarta: Bumi Aksara, 2010. Page 39. 
(brand image) and the level of public trust regarding educational services held at MA Ma'arif NU Blitar City and MA Ma'arif Udanawu Blitar Regency. When the community is invited or visited, they come into direct contact with the madrasa, this interaction allows the transfer of information from the madrasa to the community. The public will know what the existence of MA Ma'arif NU in Blitar City and MA Ma'arif Udanawu in Blitar Regency are like. If the data and information obtained by the community show good results, there will be trust and a good perception in the minds of the public regarding educational services at the two institutions. In accordance with what Kotler said that brand image is entirely a perception of everything that people see, hear, read, know, feel, think about a product or service. ${ }^{8}$ Positive perceptions and beliefs about educational services are embedded in the minds of the community, so that they are satisfied and become loyal customers of the educational services provided. Kotler in Rangkuty added that if a person's feelings meet or even exceed his expectations, that person can be said to be satisfied. ${ }^{9}$ If people believe and are satisfied with educational services at Islamic educational institutions, then the next hope is customer loyalty, where people are always loyal to using educational services without hesitation turning to other educational institutions. Johnson and Gustafson in Supranto who said that if consumers are satisfied it will lead to loyalty in using the services offered. ${ }^{10}$ This means that if the guardians of students are satisfied with the educational services held at Islamic educational institutions, they will become loyal guardians of students and even become guardians of students who have high loyalty. So if the madrasa has loyal guardians, it will have an impact on the profit of the madrasa.

\footnotetext{
${ }^{8}$ Philip Kotler, B2B Brand Management: Dengan Branding Membangun dan Memenangi Kompetensi. Jakarta: PT Bhuana Ilmu populer, 2019. Page 6.

${ }^{9}$ Rangkuti, Freddy. Measuring Customer Satisfaction. Jakarta: Gramedia Pustaka Utama, 2014. Page 23.

${ }^{10}$ Supranto, Pengukuran Tingkat Kepuasan Kepuasan Pelanggan: Untuk Menaikkan Pangsa Pasar. Jakarta: Rineka Cipta, 2011. Page 7.
} 
As stated by Tjiptono that customer loyalty is the ideal situation most marketers expect, where consumers have a positive attitude towards the product or producer (service provider) and are accompanied by a consistent pattern of repeat purchases. ${ }^{11}$ This customer loyalty is the key to the institution's interest in the community, so that every year the number of students/registrants always increases. This strengthens the opinion of Gremler and Brown in Ali Hasan which states that the community and loyal guardians of students are those who have a positive commitment and attitude towards madrasas, even recommending others to use educational services in Islamic educational institutions. ${ }^{12}$ The characteristics of guardians of students or the public who have been captivated by educational services are telling relatives, neighbors, colleagues, or relatives to use educational services organized by Islamic educational institutions, even if they do not want people they know to use educational services that are other. On the other hand, Islamic educational institutions must also carry out continuous quality improvement.

\section{b. Indirect Strategy}

Indirect strategy is a way to build an institution's brand image by not dealing directly with the target object, namely the community. The implementation uses mass media and social media channels. MA Ma'arif NU Blitar City and MA Ma'arif Udanawu Blitar Regency consider the use of social media to be more effective and efficient because it makes it easier for the public to access it, considering that currently everyone already has a cellphone that can access the internet freely anytime and anywhere. . By using social media, it is quite easy for the community to find information and communicate with institutions without having to come to the location. Some of the reasons for the MA Ma'arif NU of Blitar City and MA Ma'arif Udanawu of Blitar Regency using social media in

${ }^{11}$ Tjiptono, Manajemen Jasa Edisi 2. Yogyakarta: Andi Offset, 2001. Page 110.

${ }^{12}$ Ali Hasan, Marketing. Yogyakarta: Media Utama, 2008. Page 83. 
building a brand image is that social media has a wide range and is capable of reaching various regions, social media also provides information space that is patent or durable, costs the use of social media is also quite cheap, besides that social media can be used for two-way communication (the madrasa with the community). As stated by Wijaya that madrasa managers should be able to communicate school marketing messages that are expected by the market, madrasas as scientific institutions will be more elegant if the form of communication is presented in the form of achievement publications by independent media such as news on social media. ${ }^{13}$ As a way for a brand image to be formed in the community, both institutions through social media show the public regarding the implementation of learning, student activities, existing programs, student achievements, institutional achievements, achievements of educators and educational staff, and facilities owned.

Both institutions use the mass media to convey information because of their reach throughout Indonesia. Mass media as a means of delivering information to the wider community related to the implementation of educational services and the achievements obtained. Electronic mass media in the form of radio and television are also used by MA Ma'arif NU in Blitar City to fill religious lectures as a form of educating the public. While the mass media in the form of print that is often used by MA Ma'arif Udanawu is newspapers as a means of information to the wider community regarding activities carried out in madrasas. Mass media is an effective means to convey all information related to institutions to the public, especially related to student programs and activities, student achievement, and the implementation of student teaching and learning activities. Ismiani in Teguh stated that mass media is used to make it easier for organizations/companies to be better known by the public, the public must be sufficient in receiving information about

\footnotetext{
${ }^{13}$ David Wijaya, Pemasaran Jasa Pendidikan. Jakarta: Bumi Aksara, 2016. Page 38.
} 
the subject so that the general public/public/community can recognize it. ${ }^{14}$ In this era of advancing globalization, Islamic educational institutions must master and utilize mass media to introduce themselves to the general public because currently educational institutions are public services whose existence must be known, known, and trusted by the wider community.

The MA Ma'arif NU educational institutions in the city of Blitar and MA Ma'arif Udanawu utilize social media and mass media to make it easier for the public to get to know the institution, get information and communicate with the institution, and know that the promises in the brand image offered have been implemented in the form of programs and programs. Learning Activities. This is in accordance with what was conveyed by Kotler that brand image is also a shortcut of attributes, benefits, beliefs and values that distinguishes, reduces complexity, and simplifies the buyer's decision-making process. ${ }^{15}$ Social media and mass media are shortcuts for the public in knowing the existence of institutions. The brand image that is built through social media and mass media is a shortcut mirroring the institution to simplify the decision-making process of education consumers in utilizing the services they want/need. Through social media and mass media, people who are looking for a place to study for their families will know the advantages of Islamic educational institutions compared to other institutions, then they will collect complete information about educational services provided by these Islamic educational institutions, and in the last stage they (candidates) the student's guardian) makes an assessment of the feasibility of choosing an Islamic educational institution as the best place for education for their children.

\footnotetext{
${ }^{14}$ David Wijaya, Pemasaran Jasa Pendidikan. Jakarta: Bumi Aksara, 2016. Page 38.

15 Philip Kotler, B2B Brand Management: Dengan Branding Membangun dan Memenangi Kompetensi. Jakarta: PT Bhuana Ilmu populer, 2019. Page 6.
} 


\section{Conclusion}

The strategy used by MA Ma'arif NU in Blitar City in building the institutional brand is direct and indirect. The direct strategy is carried out by inviting the public to come directly to the institution and the institution being present in the midst of the community directly as a proactive effort to introduce, publish, market madrasas to the wider community. The indirect way used by MA Ma'arif NU in Blitar City is to convey the institution's brand through mass media and social media. Meanwhile, the strategy in building a brand image is carried out by MA Ma'arif Udanawu, Blitar Regency by directly inviting the public to come to the madrasa to know for sure the programs, activities, and achievements of the institution. MA Ma'arif Udanawu also uses an indirect strategy by utilizing online media to convey the institution's brand to the wider community.

The strategy used by Islamic educational institutions in building a brand image is through direct and indirect methods. The direct strategy is carried out by meeting face to face with the community with the aim of introducing, promoting, and marketing directly related to educational services held by madrasas. While the indirect strategy is implemented by utilizing social media and mass media because it is able to reach various areas and is easily accessible to the wider community.

\section{References}

A. Gebremedhin and Joshi, 2016. Social Justice And Human Rights In Education Policy Discourse: Assessing Nelson Mandela's Legacy, UNISA Journal. Vol 20 No 1. Page 174.

Abdurahman, Dudung, 2010. Pengantar Metode Penelitian.Yogyakarta: Kurnia Kalam Semesta, 
Agnes sukasni \& Hady Efendi, 2017. The Problematic of Education System in Indonesia and Reform Agenda, International Journal of Education. Vol. 9, No. 3 .

Agustinus Hermino, 2016. Asean Economic Community In The Perspective Of Transformational Leadership in School, International Journal of Education and Research, Vol. 4 No. 6 June 2016.

Asal Mirzai, Yaser Sobbani \& A. Slambolchi, 2016. The Branding : A Study of Brand Image, Brand Associations and Reputation, Advanced Social Humanities and Management 3 (1).

Ali Hasan, 2008 Marketing. Yogyakarta: Media Utama, Page 83.

Alma, Buchari, 2019. Manajemen Pemasaran dan Pemasaran Jasa. Bandung: Alfabeta, Page 39.

Charlene Tan, Educative Tradition and Islamic Schools in Indonesia, Journal of Arabic and Islamic Studies. Vol 14 (2014). Page 47.

David Wijaya, 2016. Pemasaran Jasa Pendidikan. Jakarta: Bumi Aksara, Page 38.

Fariani, Silvy. Aryanto. 2009. Public Relations Profesi dan Praktik. Jakarta: Salemba Humanika. Page 69.

M. Mursid, 2010. Manajemen Pemasaran. Jakarta: Bumi Aksara, Page 49.

Philip Kotler, 2019. B2B Brand Management: Dengan Branding Membangun dan Memenangi Kompetensi. Jakarta: PT Bhuana Ilmu populer, Page 6.

Rangkuti, Freddy.2014. Measuring Customer Satisfaction. Jakarta: Gramedia Pustaka Utama, Page 23. 
Supranto, 2011. Pengukuran Tingkat Kepuasan Pelanggan: Untuk Menaikkan Pangsa Pasar. Jakarta: Rineka Cipta, Page 7.

Teguh Tri Susanto, Penggunaan Spanduk Dan Brosur Sebagai Bahan Penunjang Media Publikasi Kegiatan, Jurnal ABDIMAS BSI, Vol 1 no 3 2018. Page 557.

Tjiptono, 2001. Manajemen Jasa Edisi 2. Yogyakarta: Andi Offset, Page 110.

Yakov Kedem \& Mueen Fakhereldeen, 2012. A Frame Work For The Training And Development Of Academic Managers In Higher Educations. Journal Of Internasional Scientific Publications: Educational Alternatives, Vol 10 Part 1, 2012. Page 116. 